\title{
Ethno-Botanic Treatments for Paralysis (Falij) in the Middle East
}

\author{
Aref Abu-Rabia \\ Ben-Gurion University of the Negev, Beer-Sheva, Israel \\ Email: arefabu@gmail.com
}

Received April 12, 2012; revised July 24, 2012; accepted August 9, 2012

\begin{abstract}
The goal of this paper is to describe beliefs and treatments for specific forms of Paralysis (falij) and other nervous disorders in the Middle East. Themes to be investigated include, the traditional medicinal practices used to treat Paralysis, as well as their curative methods using traditional herbal medicine. This paper is based on first and secondary sources; interviews with traditional healers, as well as patients who suffered from these disorders. The author found 152 plants species belonging to 58 families (see Appendix) that treat paralysis and other nervous disorders. The most significant plants species are found in the six families of herbs: Labiatae, Compositae, Umbelliferae, Papilionaceae, Liliaceae, and Solanaceae.
\end{abstract}

Keywords: Paralysis; Ethno Botanic Medicine; Middle East

\section{Introduction}

The use of plant medicines in the Middle East has historical roots in Ancient Arabic medicine, which itself was influenced by the ancient medicinal practices of Mesopotamia, Greece, Rome, Persia, and India. During the Umayyad rule (661-750 A.D.), translations of ancient medical works began. The Abbasids dominated the sociopolitical life of the greater part of the Muslim world from 750 to 1258 A.D. Within a century, Muslim physicians and scientists were making original contributions to medical and botanical knowledge. In Baghdad, and in other parts of the Muslim world, centers of medical learning had already been founded. The next 3 centuries saw the synthesis and creation of new drugs and therapies [1].

One of the greatest and most famous Islamic doctors was Ibn Sina (Avicenna, 980-1037 A.D.), who combined the Canon of Medicine, which includes many descriptions of uses for medicinal plants. Another Arabic philosopher-physician was al-Razi (Rhazes, 865-923 A.D.), who composed a Comprehensive Book on Medicine. This material composed was arranged under the headings of different diseases, with separate sections on pharmacologic topics. Ibn al-Baytar's (1197-1248 A.D.) work, the Compendium of Simple Drugs and Food described more than 1400 medicinal drugs, including 300 previously undocumented drugs. This scholarly medical tradition which was molded in the tenth century matured through the eleventh and twelfth centuries, reached a peak in the thirteenth through sixteenth centuries, and later declined during the seventeenth through the nineteenth centuries. Medical information grounded in Arab classical medical scholarship of the Middle Ages was gradually transferred to local traditional healers and to the general public. Arabs relied primarily on their traditional medicine [2]. In this way, Arab classical medicine became the exclusive domain of traditional medicine and folk healers in the nineteenth and twentieth centuries [3]. Most of the herbs were used both as food and as medicine [4].

Many of the plants used by the Arab have direct effects on the body as purgatives, emetics, astringents, or tonics, or cause/prevent vomiting or diarrhea. This traditional medicine is based on a practical knowledge of plants and disease treatments over centuries. It should be noted that some plants are used similarly throughout the Middle East, while some plants have different uses in different countries in the region.

Based on their patterns of life, the Arab in the Middle East belongs to three distinct ethnic groups: the urbanized (hadar); the peasants (fallahin); and the nomads and seminomad Bedouin tribes (badu) [1].

\section{Methodology}

The data for this paper are derived from a broader study of ethno-botany and folk medicine of the Middle East over three decades. The paper is based on interviews with healers and patients. Unstructured interviews and 
the observation of participants were carried out in the informants' homes (men and women), as well as in the homes of traditional healers (men and women). Most of the healers were in the age range of forty to eighty years old. All the informants were married and over thirty years old. All the material was recorded in field logs, and some was tape-recorded. Plant samples were collected and identified by healers, tribal elders, and university botanists. The samples were identified and classified according to the plant seeds, leaves, fruit, taste, color and shape.

\section{Results}

This paper describes beliefs and treatments for specific forms of Paralysis and other nervous disorders in the Middle East by traditional herbalists among the Arabs in the Middle East. In this study, we found that Arab use various parts of the plants, including leaves, flowers, barks, stems, stalks, roots, rhizomes, bulbs, tubers, fruit, corns, shells, seeds, stones/pits (in fruits), soft seed pods, grain buds, shoots, twigs, stolons, oils, resins and gums. These parts are used fresh and soft, or cooked or dried. Toxic plants/bulbs are dried, boiled several times in water, or placed in hot ashes and then used for medicines or foods. The dosages for patients with the same diseases or disorders may vary, according to the ages and the structures of the patients' bodies.

The rich variety of approaches employed by different healers to treat specific forms of paralysis and other nervous disorders is indicative of the depth and breadth of indigenous medicine practiced among the Arab in the twentieth century. It should be noted that wild desert plants also contain a host of other biologically active compounds besides nutrients. The physiological effects of these other compounds in relation to plant nutrients are not well known, but could affect nutrient and medical utilization or other functions. These topics are of relevance for future research in terms of improving our understanding of human nutritional and medical requirements of the people in the Middle East.

Analysis of the findings shows that the Middle East is the geographic origin of both wild and cultivated medicinal plants. In this research the author found 152 plants species belonging to 58 families that treat parlaysis and other nervous disorders. The most significant plants species are found in the six families of herbs: Labiatae with 21 plants, Compositae with 15 plants, Umbelliferae with 15 plants, and Papilionaceae with 10 plants, Liliaceae with 7 plants, Solanaceae with 6 plants. The appendix shows the whole families with their plants species.

This paper deals with the six representative families; the Latin name of the species is given first followed by the Arabic and English names as described below:

\section{Labiatae: (21 Plants)}

\subsection{Ballota nigra $\mathrm{L}$.}

Arabic: Ferasyoun aswad.

English: Black hemp-nettle.

Plant parts: The whole herb.

Active constituents: Essential oil, tannin, gallic acid [5].

Ethno-botanical use: Antispasmodic, to make one less nervous [5,6] and sedative (is a drug which quiets nervous activity). Flowering branches are an antispasmodic [7] and tranquilizer (a drug used in calming persons suffering from nervous tension and anxiety). Leaves and flowers are boiled in water: used as anti-spasmodic [8] and sedative.

\subsection{Coridothymus capitatus (L.) Reichb}

Arabic: Zahayfy, Za’tar Farisy.

English: Wild thyme.

Plant parts: Leaves and flowers.

Active constituents: The essential oil contains phenols: carvacrol and thymol [9].

Ethno-botanical use: Boil leaves and flowers in water, stay in the bathtub for one hour, once a day for one month to treat paralysis [10].

To treat paralysis: Prepare a steam bath from the leaves and use it daily for a month.

\subsection{Lavandula officinalis}

Arabic: Khuzama, Khuzama ma'rufa.

English: Common lavender.

Plant parts: Leaves and flowers.

Active constituents: Pinene, limonene, geraniol, borneol, essential oil, tannin [5,11]; lavender oil and coumarins [8].

Ethno-botanical use: Infusion of flowering summits or lavender oil are antispasmodic $[5,7,8]$.

\subsection{Melissa officinalis $\mathbf{L}$.}

Arabic: 'Ishbit el-Nahel, Turunjan.

English: Lemon-balm.

Plant parts: Leaves, and flowers.

Active constituents: Essential oil obtained from leaves contain citral and citronal [9].

Ethno-botanical use: Leaves and flowers used to relieve convulsions [12]. A water infusion is used as a tranquilizer; extracts of the leaves relax muscle spasms [9]. Infusion of leaves is an antispasmodic [7].

\subsection{Mentha longifolia L./Mentha piperita L./ Mentha pulegium L./Mentha spicata $\mathrm{L}$.}

Arabic: Na’na' barri, Na’na, Habaq. 
English: Mint, Horse mint.

Plant parts: Leaves.

Active constituents: Menthol, tannin, essential oil, bitter principle [5]; Magnesium and potassium [13]; commercial menthe oil (menthylacetate, menthol and menthone) [14].

Ethno-botanical use: Preparation: boil in water and drink; boil the leaves in water and drink two to four cups a day as a sedative and relieves spasms [5]. Treat muscle spasms and convulsions, and pain of facial paralysis [12]; an antispasmodic [7]; to prevent muscle spasms [9].

\subsection{Micromeria fruticosa (L.) Druce}

Arabic: Qurnya, 'Ishbit esh-shai, Duqat 'Adas.

English: Thyme-leaved savory.

Plant parts: Leaves, flowers.

Active constituents: Essential oil: novel, natural monoterpene ketone [9].

Ethno-botanical use: Drink an infusion from the leaves and flowers in order to strengthen and calm the nerves [9].

\subsection{Nepeta cataria}

Arabic: Qatram, hashishat al-her.

English: Catmint, catnip.

Plant parts: Leaves, the whole plant.

Preparation: Boil leaves in water and drink.

Active constituents: Vitamin C [13]; thymol, carvacrol and lactones [8].

Ethno-botanical use: Antispasmodic [8].

\subsection{Ocimum basilicum L.}

Arabic: Rayhan.

English: Sweet basil, basilica.

Plant parts: Leaves and seeds.

Preparation: Boil in water and drink.

Active constituents: Essential oil, tannin [5]; oil is the active ingredient which consists: thymol, linalol, cineol, eugenol, terpenes, sesquiterpenes, and methylchavicol $[11,14,15]$.

Ethno-botanical use: Used as a calming medicine [16]; used as a calming sedative and antispasmodic [8].

\subsection{Origanum vulgare $\mathrm{L}$.}

Arabic: Mardagush.

English: Oregano, Organy, wild majorana.

Plant parts: Leaves, the whole herb.

Active constituents: Essential oil, tannin, thymol, carvacrol; and vitamin C [13].

Ethno-botanical use: Antispsmodic [5]. Treats pains of facial paralysis [11,12].

\subsection{Rosmarinus officinalis}

Arabic: Iklil al-Jabal, Hasalban.

English: Rosemary.

Plant parts: Leaves, flowers.

Preparation: Boil the leaves in water and drink.

Active constituents: Essential oil, cineol, borneol, tannin, acids, resin $[5,11]$.

Ethno-botanical use: Antiepileptic [5] and antispasmodic [7].

\subsection{Salvia fruticosa Mill/Salvia officinalis $L$.}

Arabic: Marmarya, miramia, Na’ema.

English: Three-lobed sage, Sage.

Plant parts: Leaves, seeds and flowers.

Active constituents: Vitamin B complex [13]; leaves contain essential oil: phenols; and thujones which depress the central nervous system; to prevent convulsions [8,9], tannin, camphor, cineol, borneol, pinene, resin [5,11], sulfur and steroid substances [13].

Ethno-botanical use: Antispasmodic [5].

\subsection{Stachys lavandulaefolia/Stachys arabica Hornem}

Arabic: Sarmag.

English: Woundwort.

Plant parts: The whole herb.

Active constituents: Essential oil, tannins, alkaloids [5].

Ethno-botanical use: Antispasmodic [5].

\subsection{Thymbra spicata $L$.}

Arabic: Za’tar hmar, za’tar shibli.

English: Spiked thymbra.

Plant parts: Leaves and stalks.

Active constituents: Essential oil: Thujene, myrecene, alpha-terpinene, paracymene, gama-terpinene, linalool, carvacrol and betacaryophyllene [17].

Ethno-botanical use: boil green leaves and stalks in water, put in bath tub and soak your body for one hour, to treat paralyzed limbs [10].

\subsection{Thymus algeriensis Boiss. \& Reut./ Thymus serpyllum L./Thymus vulgaris}

Arabic: Khieta, zahhayfy, za'tar.

English: Thyme.

Plant parts: The whole herb.

Active constituents: Essential oil, cymol, thymol, tan$\operatorname{nin}[5]$.

Volatile oil: Phenols such as thymol, carvacrol, glycoside, and flavonoids $[11,14,15]$.

Ethno-botanical use: Leaves and flowering branches are an antispasmodic [7] and sedative [5,14]. 


\section{Compositae: (15 Plants)}

\subsection{Achillea fragrantissima (Forssk)/Achillea millefolium}

Arabic: Qaysum, qisum, umm alf waraqa.

English: Lavender cotton, yarrow.

Plant parts: Leaves, flowers.

Preparation: Boil in water and drink.

Active constituents: Flavonoids, sesquinterpene lactones, which relieve convulsions and inflammations [9]; terpenoids, sterols, lactones, and chamazulenes [14]; and Potassium [13].

Ethno-botanical uses: Used as an antispasmodic [12]. Make a vapor bath by boiling leaves and flowers, or prepare an infusion to drink, in order to treat convulsions and muscle spasms.

\subsection{Ambrosia maritima $\mathrm{L}$.}

Arabic: Damsisa.

English: Sea Ambrosia.

Plant parts: Leaves, the whole plant.

Preparation: Boil in water and drink.

Active constituents: Chlorosesquiterpene lactones [14].

Ethno-botanical uses: The whole plant is used as an antispasmodic [14].

\subsection{Anacyclus pyrethrum L. Link}

Arabic: Oud el-’attas, Agargarha.

English: Spanish pellitory.

Parts used: Roots.

Active constituents: The roots contain anacyclin [18].

Ethno-botanical use: A gargle of its infusion is prescribed for partial paralysis of the tongue and lips, relief of neuralgia and palsy [7].

\subsection{Artemisia absinthium L./Artemesia herba-alba Asso}

Arabic: Shih Rumi, Afsantin, Shih, sheeh.

English: Wormwood, absinthium.

Plant parts: Leaves, flowers.

Preparation: Boil in water and drink, or eat.

Active constituents: Vitamin C [13]. Its active substances include silica, two bitter substances (absinthin and anabsinthine), thujone, tannic and resinous substances, malic acid, and succinic acid. Essential oil, resin, pinene, cadinen, tannin [5,11]; Santonin, sterols and thujones $[11,19]$; it also contains essential oils, sesquiterpene lactones and thymol; leaves and stems contain three nonglycosidic flavonoids [14].

Ethno-botanical uses: To treat nervousness: prepare a sweetened extract, from the leaves, in glass of water and drink it [9]; to treat paralysis [20]. It is also used as an antispasmodic and calmative (having relaxing/quieting effect or pacifying properties).

\subsection{Atractylis gummifera $\mathrm{L}$.}

Arabic: Heddad, Shawk el-'elk. English: White chameleon, Spindle wort.

Plant parts: Leaves and flowers.

Active constituents: Verapamil, or dithiothreitol [21].

Ethno-botanical use: Root fumigant for paralysis; infusion of flowers for epilepsy and convulsions, paralysis of lips [7].

\subsection{Calendula officinalis $\mathbf{L}$.}

Arabic: Uqhuwan.

English: Marigold.

Plant parts: Leaves, flowers and fruit.

Preparation: Boil in water and drink.

Active constituents: Calendulin, essential oil, acids mucilage and carotenoides [5]; Vitamin A and phosphorrus [13].

Ethno-botanical uses: Flowers are used as an antispasmodic $[7,11]$.

\subsection{Carthamus tinctorius $\mathbf{L}$.}

Arabic: Qurtum, zafaran, ’usfur.

English: Safflower.

Plant parts: Flowers and seeds.

Active constituents: Carthamin, fixed oil, yellow and red coloring matters [5]. Safflower seeds are the source of oil [13]; flowers contain palmitic acid, myristic acid and lauric acid; flavonoids and sterols; seeds contain aphenolic amide [14].

Ethno-botanical use: Boil flowers in water for $15 \mathrm{~min}-$ utes, filter, and drink five table spoons a day, to treat paralyzed body organs [10].

\subsection{Chrysanthemum coronarium $\mathrm{L}$.}

Arabic: Bisbass, Sufirah, balsamiya.

English: Chrysanthemum.

Plant parts: Leaves and flowers.

Active constituents: Sesquiterpene lactones [9].

Ethno-botanical use: Use the leaves in a steam bath to relieve muscle aches, nervousness and contractions of the uterus [9]; sedative and antispasmodic [8].

\subsection{Echinops ritro L.}

Arabic: Qunfudhiya.

English: Globe thistle.

Plant parts: Flowers and seeds.

Active constituents: Echinospine, oil and minerals [5].

Ethno-botanical use: Antispasmodic and neurotonic 
[5].

\subsection{Inula viscose (L.) Ait}

Arabic: 'Irq al-Tayun, Tayun.

English: Inula, Elecampane, clammy inula.

Plant parts: Leaves, roots and the whole herb.

Preparation: Boil in water and drink.

Active constituents: Inulin, levulin, mucilage, essential oil [5]; flavonoids: Quercetin and inulin [9].

Ethno-botanical use: To cure muscle cramps-prepare a steam bath with the leaves or the whole herb; treat local paralysis: Extract oil from the leaves and massage the affected area. For nervousness, prepare a decoction from the roots and spread it on the body [9]. Or soak the leaves in water and drink a table spoon a day for one week as a tranquilizer.

\subsection{Lactuca serriola $\mathrm{L}$.}

Arabic: Khass Barri.

English: Oil lettuce, Prickly lettuce.

Plant parts: Leaves, stems and stalks.

Preparation: Eat as raw salad.

Active constituents: Alkaloids, flavonoids and saponin [22].

Ethno-botanical use: Calmative and antispasmodic [7].

\subsection{Matricaria recutita $\mathrm{L}$.}

Arabic: Uqhuwan, kahwan, babounaj.

English: Wild chamomile, German Chamomile.

Plant parts: Flowers, the whole herb.

Active constituents: Essential oil, vitamin C, coumarin, apigenin [5]; potassium [13]; volatile oil; proazulene, flavoles and coumarines; apigenin glycosides [14].

Ethno-botanical use: Flowers are an antispasmodic [7] and sedative [8].

\subsection{Silybum marianum L.}

Arabic: Khurfeish al-jamal, shouk al-jamal.

English: Milk thistle, St. Mary's Thistle.

Plant parts: Shoots, the whole herb, seeds.

Preparation: To be eaten as raw salad; or boiled in water and drank.

Active constituents: Tyramine, tannin, resin, fixed oil [5]; seeds contain a mixture of glycosides known as silymarine. Silymarine contain active ingredients: Silybin, silychristin, and silydianin [9].

Ethno-botanical use: Antispasmodic [5].

\section{Umbelliferae: (15 Plants)}

\subsection{Ammi visnage $\mathrm{L}$.}

Arabic: Khella, Saq al-'Arus.
English: Bishop’s weed.

Part used: Seeds.

Active constituents: In modern medicine-substances produced from this plant are: Khellin, visnagin, visnadin and khellol-they are spasmolytic agents, and relax various smooth muscles $[9,11]$.

Ethno-botanical use: To prepare a water infusion of the crushed seeds, and drink one cup a day, as an antispasmodic [5,7], and to prevent muscle spasms [11,12].

\subsection{Anethum graveolens $\mathrm{L}$.}

Arabic: Shebet, 'ayn Jaradeh.

English: Dill.

Plant parts: Seeds and flowers, fruit.

Active constituents: Essential oil, terpenes, carvone, fixed oil, tannin [5]; sulfur [13]; essential oil: carvone [9]; seeds contain volatile oil: Anethofuran, carvone and limonene [14].

Ethno-botanical use: Fruit is used as an antispasmodic and sedative [7]; and as tranquilizer.

\subsection{Apium graveolens $\mathrm{L}$.}

Arabic: Karafs.

English: Celery.

Part used: Leaves, roots and seeds.

Active constituents: The seeds contain essential oils of which the main components are limonene and apiol [9,11]; Essential oil, apiin, asparagin, limonene [5].

Ethno-botanical uses: Roots are used in the form of infusion for relaxing nervous tension, and is antispasmodic [5,11].

\subsection{Carum carvi L.}

Arabic: Krawya, Karawiya.

English: Caraway, common caraway.

Plant parts: Flowers and seeds.

Active constituents: Essential oil, fixed oil, carvone, resin, tannin, coumarins [5]; and phosphorus [13].

Ethno-botanical use: Analgesic, ripe fruits are a nerve calmative; ripe seeds antispasmodic [7,11].

\subsection{Conium maculatum}

Arabic: Shiqran, Shawkaran.

English: Poison-hemlock, Hemlock.

Plant parts: Dried leaves, seeds and roots.

Preparation: The dried leaves are soaked in water and drunk, a table spoon a day for two weeks.

Active constituents: Essential oil, coniine, conhydrine, conicein [5]; alkaloids: Coniine, being the toxic constituent, found in all parts of the plant [9]; Coniilne and conhydrine [11].

Ethno-botanical use: Treat nervous excitability, acting 
on the paralysis tremors. Young branches and ripe fruits is effective as a tranquilizer, analagesic, prophylactic muscle relaxant; neuroleptic, antidepressant, and anticonvulsant [5,9]. The tincture is prescribed as a neuromuscular sedative and antispasmodic for a paralyzed respiratory system $[7,11]$.

\subsection{Coriandrum sativum $\mathrm{L}$.}

Arabic: kuzbarah, kusbara.

English: Coriander.

Plant parts: seeds and leaves.

Preparation: boil in water and drink.

Active constituents: Essential oil, corinadrol [5]; and Vitamin C [13]; essential oil from the fruit has high content of linalol, a material which is used in the production of vitamin $\mathrm{A}$; leaves are a source of vitamin $\mathrm{A}$, and $\mathrm{C}$; and coriander oil [9]; fruit and leaves contain: fats, protein, volatile oil [14].

Ethno-botanical use: The distilled essential oil from the fruits relieves muscle pains, and acts as a tranquillizer [9], antispasmodic [5], sedative and treat nervous disorders [7].

\subsection{Cuminum cyminum $\mathrm{L}$.}

Arabic: Kamun, sannut.

English: Cumin.

Plant parts: Seeds.

Active constituents: Cuminol, carvone, essential oil, cymol, cuminic aldehyde [5]; seeds contain volatile oil [14].

Ethno-botanical use: infusion of fruits antispasmodic [7] and sedative [14].

\subsection{Daucus carota L. Subsp}

Arabic: Jazar barri, jiziyr.

English: Wild carrot.

Plant parts: fruit, roots and seeds.

Preparation: eaten as raw food.

Active constituents: Vitamin A and B, pytosterine, carotin, asparagine, minerals [5]; Vitamins A, B6, B complex, and C; Chloride compounds, magnesium, potassium, sodium and iron; it is a source of carbohydrates [13]; roots contain glucose, sucrose, protein, salts, pectin, carotene, vitamins and asparagine; seeds contain: pinene, limonene, carotol, daucol, isobutyric acid and asarone [14].

Ethno-botanical use: fruits are an antispasmodic [7], and sedative [14].

\subsection{Eryngium creticum Lam}

Arabic: Kursannih.

English: Eryngo, Snake root.
Plant parts: roots.

Preparation: boil in water and drink.

Active constituents: Sugar, saponins, essential oil [5].

Ethno-botanical use: to strengthen the nerves, to treat paralysis and nervous diseases [14].

\subsection{Pimpinella anisum/Pimpinella cretica Poirt}

Arabic: Yansun.

English: Anise, Sweet cumin, Aniseed plant.

Plant parts: seeds and flowers.

Active constituents: essential oil, anethol, fixed oil, choline, mucilage [5]; anisic acid, fats, protein and sugar [14].

Ethno-botanical uses: To treat convulsion, facial paralysis boil seeds in water, and allow the body to obserb the steam. The steams contain essential oil which affect on the face convulsions and heal them [10]. Seeds treat spasms $[6,11]$.

\subsection{Ferula asafetida/Ferula communis/Ferula narthex}

Arabic: haltit, Simgh al-Unjadhan, Jiddeh.

English: Asafoetida.

Plant parts: resin: oleo-gum-resin.

Preparation: boiled in water and drunk, chewed, or burn on coals for inhaling the smoke.

Active constituents: Sulfur [13]. The oleo-gum-resin, asafetida, is obtained from the plant's rhizome; it consist volatile oil which contain sulphur compounds; the resinous portion include asaresinol ferulate and free ferulic acid $[11,23]$.

Ethno-botanical use: the oleo-gum-resin is used as an antispasmodic [7,14].

\subsection{Foeniculum vulgare Mill}

Arabic: Shawmar.

English: Fennel.

Plant parts: Stems, leaves and seeds.

Preparation: Boil leaves in water and drink two cups a day for three weeks.

Active constituents: Essential oil, anethole, anisic acid, acids, fixed oil [5]; Potassium and sulfur [13]; from the fruit we get fennel oil: anethole and enol; liquorice and senna [9]; seeds contain volatile oil; phenolic anethole and a ketone fenchone [14].

Ethno-botanical use: the fruit is an antispasmodic and calmative $[7,11,12]$.

\section{Papilionaceae: (10 Plants)}

\subsection{Glycyrrhiza glabra L.}

Arabic: 'Irq al-sus, 'ud al-sus. 
English: Liquorices, licorice.

Plant parts: leaves, rhizome.

Preparation: boil in water and drink.

Active constituents: Glycyrrhizin asparagine, liquirtin, coumarin, sugar, tannin [5], and phosphorus; and steroid substances [13]; glycyrrhizin and glycyrrhetic acid [9]; the plant is a source of licorice, the sweet taste due to glycyrrhizin (the calcium and potassium salts of glycyrrhizinic acid); flavonoids, starch, protein and bitter principles [11,14].

Ethno-botanical use: to relax uterine muscles, antispasmodic $[7,8]$, and tranquilizer, sedative, rhizome is used for treating muscle pain [14].

\subsection{Lotus corniculatus}

Arabic: qarn al-ghazal, beseli.

English: Bird's foot.

Plant parts: flowers.

Active constituents: cyanogenetiques, flavonoides [8]. Ethno-botanical use: sedative and antispasmodic [8].

\subsection{Medicago sativa $\mathrm{L}$.}

Arabic: khubz al-Ra'ay, barsim hijazy.

English: Medick, locerne, alfalfa.

Plant parts: leaves, seeds, and the whole herb.

Active constituents: Saponin, alkaloids [5]; Vitamins A, C, K and B complex; and enzymes [13]; saponin, glucose and medicagenic acid; lucernic acid, oil, flavonoids, alkaloids and phenols [14].

Ethno-botanical use: sedative which quiets nervous activity [14].

\subsection{Melilotus alba/Melilotus indicus (L.) All}

Arabic: nafal.

English: Scented trefoil.

Plant parts: leaves, and flowers.

Active constituents: coumarins and flavonoids, terpenoid glycosides, herniarin, choline and aromatic compound [14].

Ethno-botanical use: infusion of flowering branches is an antispasmodic [7].

\subsection{Retama raetam (Forssk.) Webb}

Arabic: ratam, ratama.

English: white broom, ratame.

Plant parts: The whole herb, flowers.

Active constituents: Essential oil [5]; alkaloids: retamine and sparteine [9].

Ethno-botanical use: to treat limb paralysis: use the upper branches to prepare a vapor bath; to treat local paralysis: use the roots-boil in water and spread the extract on the affected area [9].

\subsection{Trifolium arvense/Trifolium pratense/Trifolium purpureum}

Arabic: barsim ahmar, abu d'alabish, naflih.

English: red clover.

Plant parts: leaves and roots.

Active constituents: Tannin, trifoline, isotrifoline [5].

Ethno-botanical uses: used as sedative and an antispasmodic; treat emotional tension and strain [10,24].

\subsection{Vicia faba $\mathrm{L}$.}

Arabic: Foul, fool.

English: broad bean.

Plant parts: broad bean/brown bean.

Preparation: eat as coked food, eat broad bean once a day for two to three weeks.

Active constituents: Vitamin B1, B complex; Phosphorus, potassium, copper and iron [13].

Ethno-botanical uses: flowers are an antispasmodic [7].

\section{Liliaceae: (7 Plants)}

\subsection{Asphodelus aestivus/Asphodelus fistulosus/Asphodelus ramosus/ Asphodelus microcarpus Salzm. \& Viv}

Arabic: Swai.

English: Asphodel.

Plant parts: roots, leaves, flowers, seeds and bulbs.

Preparation: boil in water and drink.

Active constituents: Asphodeline, inuline, mucilage [5], Alkaloids, glycosides and anthraquinones [9].

Ethno-botanical use: antispasmodic [5]. Rubbing the body with roasted tubers and drinking decoction from leaves treats paralysis [7].

\subsection{Lilium candidum L.}

Arabic: Zanbaq, Sawsan abyad.

English: White lily.

Plant parts: flowers and bulbs, leaves or dried seeds.

Preparation: soak in water and drink.

Active constituents: Scillin, minerals, mucilage, pectinds [5].

Ethno-botanical use: antispasmodic [5].

\subsection{Ruscus aculeatus L.}

Arabic: Ass Barri, Khizana.

English: Butcher's broom, Kee holly.

Plant parts: roots, leaves.

Preparation: boil in water and drink.

Active constituents: mixture of sterols and fatty acids [9].

Ethno-botanical use: An infusion of the flowers tran- 
quilizes the nerves and calms hysterical seizures and convulsions; a decoction of the branches mitigates convulsions [9].

\subsection{Urginea maritima L. Bak}

Arabic: halluf, 'Unsol, bussayl.

English: Squil white.

Plant parts: leaves, bulbs.

Active constituents: Urginin, cardiotonic glycosides, scillaren, mucilage [5,11]; bulbs contain glycoside: proscillaridin A.

Ethno-botanical uses: treatment of cathartic and upset nerves $[7,11]$.

\section{Solanaceae: (6 Plants)}

\subsection{Atropa belladonna L.}

Arabic: Set al-Husn.

English: Deadly nightshade, Belladona.

Plant parts: leaves and roots.

Active constituents: atrosin [5]; atropine, hyoscyamine and hyoscine cocaein [11].

Ethno-botanical use: antispasmodic and sedative [5, 11].

\subsection{Datura stramonium L.}

Arabic: Daturah, Semm al-far.

English: Jimsonweed, thorn-apple.

Plant parts: leaves, seeds and roots.

Active constituents: active ingredients like alkaloids of the tropane group, such as atropine, scopolamine and hyoscamine [9]; daturine, hyoscyamine, atropine, scopolamine, hyocine [5,11].

Ethno-botanical use: sedative, analgesic, antispasmodic, for asthma and neuralgic pain; acts as a tranquillizer. Tincture of leaves prescribed for spasmodic coughs and asthma; leaves used in fumigations and in cigarettes to ease asthma attacks [5]. Atropine is one of the active ingredients in this plant. Its physiological activity is mainly on the central nervous system. It is used to prevent convulsions of the smooth muscles, especially in the lower part of the body [9]. Leaves acts as an antispasmodic and sedative $[7,11]$.

\subsection{Hyoscyamus albus L./Hyoscyamus aureus}

Arabic: Sikiran, banj.

English: White henbane.

Part used: Leaves and seeds.

Active constituents: Alkaloids, hyoscyamine, hyoscypicrin, essential oil [5]; atropine and hyoscine [11].

Ethno-botanical use: plant alleviates nervous irritation such as various forms of hysteria [7]; calmative, tranquilizer for hysteria and nervousness $[9,11]$.

\subsection{Nicotiana tabacum L.}

Arabic: teten, tebgh, dukhan

English: Tobacco

Plant parts: Leaves.

Active constituents: Nicotine compounds [5]; nicotine and anabacine [11].

Ethno-botanical use: CNS stimulant followed by depression, hypertensive [5]; smoking dried leaves as tranquilizer and antispasmodic.

\subsection{Solanum nigrum $\mathrm{L}$.}

Arabic: Enab eddib, 'Enb al-Tha’lab.

English: Black nightshade.

Part used: The whole herb, fruit (berries) and seeds. Unripe berries are poisonous, ripe berries are edible.

Active constituents: Saponin, solanine [5,9]; Vitamin $\mathrm{C}$ and carotenes [14]; solasodine [11].

Ethno-botanical use: sedative, antispasmodic [5]. Leaves to relieve nervous pains: use the leaves, prepare a decoction and massage with it; the fruit have a narcotic and tranquilizing effect; extracts of this plant suppress the activity of the central nervous system and prevent muscle spasms [9].

\section{REFERENCES}

[1] A. Abu-Rabia, "Palestinian Plant Medicines for Treating Renal Disorders: An Inventory and Brief History,” Alternative \& Complementary Therapies, Vol. 11, No. 6, 2005, pp. 295-300. doi:10.1089/act.2005.11.295

[2] A. Abu-Rabia, "The Bedouin's Traditional Medicine," Mod Publishing, Tel-Aviv, 1999.

[3] E. Lev, "Reconstructed Material Medica of the Medieval and Ottoman al-Sham," Journal of Ethnopharmacology, Vol. 80, No. 2-3, 2002, pp. 167-179. doi:10.1016/S0378-8741(02)00029-6

[4] M. Ali-Shtayeh, Z. Yaniv and J. Mahajna, "Ethnobotanical Survey in the Palestinian Area: A Classification of the Healing Potential of Medicinal Plants," Journal of Ethnopharmacology, Vol. 73, No. 1-2, 2000, pp. 221-232. doi:10.1016/S0378-8741(00)00316-0

[5] F. Karim and S. Qura'an, "Medicinal Plants of Jordan,” Yarmouk University, Irbid, 1986.

[6] J. Philips, “Lebanese folk cures,” University Microfilms, Ann Arbor, 1958.

[7] L. Boulos, "Medicinal Plants of North Africa,” Reference Publications, Algonac, 1983.

[8] H. Qubaysi, "Mu'jam al-a’Shab wal-Nabatat al-Tibbiya," Dar al-Kotob al-Ilmiyah-Publishing Haouse, Bayrut, 1998.

[9] D. Palevitch and Z. Yaniv, "Medicinal Plants of the Holy Land,” Modan Publishing House, Tel-Aviv, 2000.

[10] N. Krispil, "Medicinal Plants in Israel and throughout the World: The Complete Guide," Hed Arzi Publishing House, Yehuda, 2000. 
[11] A. Atyat, "Production and Processing of Medicinal and Aromatic Plants in the Arab World," Arab Institute for Research and Publications (in Arabic), Bayrut, 1995.

[12] A. Khalifa, “al-Nabatat: Saydaliyat al-Taby'ah,” al-Markaz al-Thaqafi al-’Arabi (in Arabic), Bayrut, 1998.

[13] J. Lust, “The Herb Book,” Bantam Books, Turonto and New York, 1980.

[14] S. Ghazanfar, "Handbook of Arabian Medicinal Plants," CRC Press, London, 1994.

[15] S. Ghazanfar and A. Al-Sabahi, "Medicinal Plants of Northern and Central Oman (Arabia),” Economic Botany, Vol. 47, No. 1, 1993, pp. 89-98. doi:10.1007/BF02862209

[16] M. Akhmisse, "Medicine, Magie et Sorcellerie au Maroc ou L'Art traditionnel de guerir," d'Impression Eddar elBeida, Casablanca, 1985.

[17] M. Inan, M. Kirpik, K. Alpaslan and S. Kirici, "Effect of Harvest Time on Essential Oil Composition of Thymbra Spicata L. Growing in Flora of Adıyaman," Advances in Environmental Biology, Vol. 5, No. 2, 2011, pp. 356-358.

[18] O. Gautam, S. Verma and S. Jain, “Anticonvulsant and
Myorelaxation Activity of Anacyclus pyrethrum DC. (Akarkara) Root Extract,” Pharmacologyonline, Vol. 1, No. 1, 2011, pp. 121-125.

[19] P. Tal, “Medicinal Plants,” Rshafim, Tel-Aviv, 1981.

[20] A. Ibn al-Baytar, "al-Jami’ li-Mufradat al-Adwiya wa'lAghdhiya (Compendium of Simple Drugs and Food)," Dar al-Kutub al-‘Ilmiya, Bayrut, 1992.

[21] C. Danielea, S. Dahamnab, O. Firuzia, N. Sekfalib, L. Sasoa and G. Mazzantia, "Atractylis Gummifera L. Poisoning: An Ethnopharmacological Review,” Journal of Ethnopharmacology, Vol. 97, No. 2, 2005, pp. 175-181. doi:10.1016/j.jep.2004.11.025

[22] F. Mojab, K. Mohammad, N. Ghaderi and H. R. Vahidipour, "Phytochemical Screening of Some Species of Iranian Plants," Iranian Journal of Pharmaceutical Research, Vol. 2. No. 2, 2003, pp. 77-82.

[23] G. Appendino, S. Tagliapietra, G. M. Mano and J. Jakupovic, "Sesquiterpene Coumarin Ethers from Asafetida," Phytochemistry, Vol. 30, No. 1, 1994, pp. 183-186.

[24] C. Townsend and G. Evan, "Flora of Iraq,” Ministry of Agriculture and Agrarian Reform of Iraq, Baghdad, 1974. 


\section{Appendix of Families and Their Plants Species}

Amaryllidaceae: Narcissus pseudo-narcissus.

Anacardiaceae: Pistacia lentiscus.

Apocynaceae: Adenium obesum.

Araliaceae: Hedera helix.

Asclepiadaceae: Calotropis procera.

Asteraceae: Santolina chamaecyparissus.

Cannabaceae: Cannabis sativa, Humulus lupulus.

Capparaceae: Capparis cartilaginea, Capparis spinosa.

Caryophyllaceae: Stellaria media.

Celastraceae: Catha edulis.

Cesalpiniaceae: Cassia italic.

Chenopodiaceae: Chenopodium ambrosioides, Chenopodium vulvaria.

Compositae: Achillea fragrantissima, Achillea millefolium, Ambrosia maritime, Anacyclus pyrethrum, Artemisia absinthium, Artemesia herba-alba, Atractylis gummifera, Calendula officinalis, Carthamus tinctorius, Chrysanthemum coronarium, Echinops ritro, Inula viscose, Lactuca serriola, Matricaria recutita, Silybum marianum.

Cruciferae: Anastatica hierochuntica.

Cucurbitaceae: Citrulus colocynthis Schirad, Ecballium elaterium.

Cupressaceae: Juniperus excelsa.

Cyperaceae: Cyperus rotundus.

Euphorbiaceae: Ricinus communis.

Fabaceae: Lablab purpureus.

Fumariaceae: Fumaria officinalis.

Gramineae: Avena sativa, Cymbopogon proximus, Lolium temulentum, Zea mays.

Hypericaceae: Hypericum perforatum.

Juglandaceae: Juglans regia.

Iridaceae: Crocus sativus.

Labiatae: Ballota nigra, Coridothymus capitatus, Lavandula officinalis, Melissa officinalis, Mentha longifolia, Mentha piperita, Mentha pulegium, Mentha spicata, Micromeria fruticosa, Nepeta cataria, Ocimum basilicum, Origanum vulgare, Rosmarinus officinalis, Salvia fruticosa, Salvia officinalis, Stachys lavandulaefolia, Stachys arabica Hornem, Thymbra spicata, Thymus algeriensis, Thymus serpyllum, Thymus vulgaris.

Lauraceae: Laurus nobilis.

Leguminosaae: Robinia pseudo-acacia.

Liliaceae: Asphodelus aestivus, Asphodelus fistulosus, Asphodelus ramosus, Asphodelus microcarpus, Lilium candidum, Ruscus aculeatus, Urginea maritime.

Loranthaceae: Viscum album, Viscum cruciatum.

Lythraceae: Lawsonia inermis.

Malphigiaceae: Acridocarpus orientalis.

Mimosaceae: Acacia nilotica, Acacia Arabica, Acacia ehrenbergiana, Prosopis farcta.

Moraceae: Ficus carica, Morus alba.

Myristicaceae: Myristica fragrans.

Myrtaceae: Eucalyptus globules.

Nymphaeaceae: Nymphaea alba.

Paeoniaceae: Paeonia coriacea, Paeonia officinalis.

Papaveraceae: Papaver somniferum.

Papilionaceae: Glycyrrhiza glabra, Lotus corniculatus, Medicago sativa, Melilotus alba/Melilotus indicus, Retama raetam, Trifolium arvense, Trifolium pretense, Trifolium purpureum, Vicia faba.

Passifloraceae: Passiflora incarnate.

Pedaliaceae: Sesamum orientale.

Piperaceae: Piper nigrum

Primulaceae: Cyclamen persicum.

Punicaceae: Punica granatum.

Ranunculaceae: Adonis aestivalis, Anemone coronaria, Delphinium staphisagria, Nigella sativa.

Rhamnaceae: Ziziphus lotus, Zizyphus spina-christi.

Rosaceae: Crataegus aronia/Crataegus monogyna, Rosa canina.

Rubiaceae: Rubia tinctorum, Rubia tenuifolia.

Rutaceae: Citrus aurantium, Haplophyllum tuberculatum, Ruta chalepensis,

Salicaceae: Salix alba.

Solanaceae: Atropa belladonna, Datura stramonium, Hyoscyamus albus, Hyoscyamus aureus, Nicotiana tabacum, Solanum nigrum.

Scrophulariaceae: Verbascum eremobium.

Tiliaceae: Tilia cordata.

Umbelliferae: Ammi visnage, Anethum graveolens, Apium graveolens, Carum carvi, Conium maculatum, Coriandrum sativum, Cuminum cyminum, Daucus carota, Eryngium creticum, Ferula asafetida, Ferula communis, Ferula narthex, Foeniculum vulgare, Pimpinella anisum, Pimpinella cretica Poirt.

Urticaceae: Urtica pilulifera.

Verbenaceae: Aloysia triphylla, Verbena officinalis, Vitex agnus-castus.

Zingiberaceae: Zingiber officinalis.

Zygophyllaceae: Balanites aegyptiaca, Peganum harmala, Tribulus terrestris. 